\title{
Analysis of Drug Trafficking and Corruption Nexus in Economic Cooperation Organization (ECO) Region
}

\author{
Salawati Mat Basir ${ }^{1}$, Mohammad Naji Shah Mohammadi ${ }^{1} \&$ Elmira Sobatian ${ }^{1}$ \\ ${ }^{1}$ Faculty of Law, Universiti Kebangsaan Malaysia, Bangi, Malaysia \\ Correspondence: Mohammad Naji Shah Mohammadi, Faculty of Law, Universiti Kebangsaan Malaysia, Bangi, \\ Selangor, 43600, Malaysia. Tel: 60-14-226-6247. E-mail: n.shahmohammadi@siswa.ukm.edu.my
}

Received: December 10, 2015

Accepted: February 18, 2016 Online Published: March 18, 2016

doi:10.5539/ass.v12n4p53

URL: http://dx.doi.org/10.5539/ass.v12n4p53

\begin{abstract}
The main objective of Economic Cooperation Organization (ECO) is economic development in its region but directly unproductive profit seeking activities such as drug trafficking is the prominent barrier to reach this goal. All members spend lots of money to fight against drug trafficking, as all of them suffer from drug addiction and drug related problems. The first step to cope with this problem is to identify the factors and incentives that make this region vulnerable for drug trafficking activities and to unearth what makes this region a haven for drug traffickers. A bulk of literature supports the concept that organized criminal organizations are not able to operate when there are not any forms of corruption since they are strongly interrelated. In this paper, we analyze the link between drug trafficking and corruption in ECO region in order to develop ECO strategies to hamper and interrupt these transnational crimes. Corruption has posed major challenges to the efforts taken to control drug and also has seriously damaged the ECO members' image in international community. One of the practical solutions is the responsibility of ECO organization in implementing rule of law in the region. Undoubtedly, fighting against corruption in ECO region is a joint responsibility of international and intercontinental community and this responsibility requires collective action and cooperation among countries in the region.
\end{abstract}

Keywords: ECO, drug trafficking, corruption, economic development, Afghanistan, Central Asia

\section{Introduction}

Economic Cooperation Organization (ECO) is the biggest economic association among Islamic countries and second regional cooperation organization in the world, whose activity covers an area of 7,000,211 square kilometers with the population of more than 350 million people (ecosecretariat.org). ECO's Main objective is economic development in its region and directly unproductive profit seeking activities such as drug trafficking is a tight barrier to reach this goal (Barro, 1991). ECO member states are among a big producer of opium and heroin in the world (United Nations Office on Drugs and Crime, UNODC, 2011) and all trafficking routes used for trafficking illicit drugs to the world pass through ECO countries (UNODC, 2011). All members spend lots of money to fight against drug trafficking, as all of them suffer from drug addiction and drug related problems .These problems are of the reasons that slow down development in the area. Mac Coun and Reuter (2001) reported that trafficking illicit drugs can affect developing countries by initially framing the effects of illicit drugs on development in terms of their impact on social stability and human and social capital, economic development, and political stability. Based on ECO objectives, it is necessary for ECO organization to take measures and address this issue. To this end, the first step to cope with this problem is to identify the factors and incentives that make this region vulnerable for drug trafficking activities and to unearth what makes this region a haven for drug traffickers. This is a legal research, which uses a qualitative method with a critical and structured descriptive approach to analyze the link between drug trafficking and corruption in ECO region in order to develop ECO strategies to hamper and interrupt these transnational crimes.

\section{Corruption}

Different perspectives have presented different definitions for the term 'corruption', for example, in bureaucratic views, corruption is termed as "illicit conduct used by individuals or groups to gain influence over the bureaucracy's actions" (Garrido, 1997). In public interest perspective, corruption is regarded as any kind of violation of the public interests to gain special advantages (Garrido, 1997); and also any conduct which goes astray from the normal, standard duties inbuilt to the public welfare in consequence of private interests, 
including their family, clan, and friendship, in order to obtain personal benefits in terms of money or social status.

Carvajal (1999) states corruption usually involves agent-client relationships, exploitation of public office as well as violations of public interests. Transparency International (transparency.org) defines corruption as the misuse of entrusted power in favor of private gain, and indicates that corruption, in general, takes two diverse forms. The first type is according to the rule, involving paying a bribe in return for regular but preferential conduct, and the second one is against the rule in which the bribe is paid in order to make someone perform something which he/she is not allowed to do. Conversely, the Asian Development Bank (1998) describes corruption as conduct that officials engage in and inappropriately unlawfully make themselves and those close to them rich or provoke others to do so.

Corruption which has impact on drug trafficking is a significant factor bringing about weakness in developing states (Andreas, 1996), particularly countries with leading part in drug trafficking. Likewise, corruption is described as a hindrance to the development and sustainment of democracies where national wealth is exploited by small proportion of the population (Basar, 2012). According to International Monetary Fund (1997), impediment of economic growth; misallocation of talent connected instead of qualified individuals obtain coveted positions; reduction in the effectiveness and usefulness of international assistance; and losing tax revenue since bribes might be paid in order to escape taxes and customs are considered as major economic consequences of corruption.

\section{Literature Review}

A bulk of literature supports the concept that organized criminal organizations are not able to operate when there are not any forms of corruption since they are strongly interrelated. According to Freeman (reported in Morris, 2013), organized crime seeks for opportunities to generate and intensify corruption as it is not able to survive without it. She further claims that doing business involves bribing and threatening public officials, law enforcement officials and judicial agents. Not only does the organized crime make corruption in the government, but also corrupt states create organized crime. Correspondingly, Peter Andreas argues (1998) "corruption is two way street and involves not only the penetration of the state but also penetration by the state".

Usually corruption has important role in and affect drug trafficking. Indeed, sometimes, corruption makes it hard to distinguish violators from enforcers (Morris, 2013). The majority of scholars (Naylor, 2009), (Pimental, 2003) and (Shelley, 2005) are of the opinion that there is a linkage between corruption and drug trafficking, and also they concur that several organized crimes such as drug trafficking cannot be operated without corruption. Beittel (2011) indicated that, corruption brings about neutralizing government action against the organization of drug trafficking, ensure impunity, and ease smooth operations. Naylor (2009) emphasizes that illegal payoffs to local officials and police not only allow these businesses to continue, but also maintain their activities and authority within specific geographic and political boundaries.

\section{Corruption and Drug Trafficking Linkage in ECO Region}

The corruption perceptions index (CPI) is particularly low in ECO region compared to the world average (transparency.org). Afghanistan ranks as the 172th country out of 175 according to the 2015 Transparency International corruption perception index (CPI) (transparency.org). Other ECO members face similar problems. It seems that this situation makes the region vulnerable for trafficking, especially central Asian countries which are the main route for trafficking drugs from Afghanistan to Russia and Europe. ECO is the most important region in terms of trafficking of Afghan heroin to Russia and remote areas in Europe. Heroin is being trafficked from Tajikistan to Kyrgyzstan (mainly) or Uzbekistan or directly to Russia (by air) (UNODC, 2009). The 2015 CPI for Tajikistan, Kazakhstan and Kyrgyzstan is very low and they have favorable environment for developing organized crime and corruption (transparency.org).

\subsection{Corruption in Main Producer Country}

Data shows (transparency.org) that the level of corruption in Afghanistan, as the main drug producer country in $\mathrm{ECO}$, is extremely high. The recent research on Afghanistan discloses a more intricate and negotiated link between drug trafficking and the business of policing drug trafficking. In January 2010, the United Nations Office on Drugs and Crime (UNODC) publicized a report titled as "Corruption in Afghanistan". This report revealed that, in 2009, Afghans paid USD 2.5 billion in the form of bribes and kickbacks, equivalent to $23 \%$ of Afghanistan's Gross Domestic Product (GDP) (Gonzalez, 2011). Reports (Checchia, 2012) also show that almost a quarter of Afghans have paid bribes to the Afghan National Police (ANP), supposed to take full responsibility in terms of establishing security all over the country by the year 2014 with Afghan National Army (ANA). It is 
widely claimed that bribable officials working in the Kabul government, the Afghan National Police (ANP), and different provincial administrations are believed to be paid by opium traffickers (Peters, 2009). Corruption has spread out throughout the government in consequence of officials' dealing with the business of the drug trade. Hence, corruption is a critical concern since it arguably leads as much to continuous insecurity in the south of Afghanistan where the insurgency is carried out through creating a perverse motivation for corrupt officials to set up good governance (Peters, 2009). According to a British study in 2008, numerous Afghans in the south of the country believe that state actors make larger profits from the business of drug trade compared to the insurgents (Peters, 2009). According to the director of an Afghan research institute, "Government officials and police officers are much more involved in drugs trade than the Taliban; after all, they hold the positions you need to facilitate the higher-level trade (Jelsma, 2009)." There are serious accusations that officials are receiving reimbursement from organized drug traffickers in return for protection and some may have a direct involvement in the drug trade (UNODC, 2009).

In Afghanistan, there are both high level and low level corruption (Basar, 2012). The majority of corruption in Afghanistan is low-level, such as "gift payments" to public officials and to other service providers, including the private sector (Myint, 2000). This corruption of course has a negative impact, for example, it can increase the costs of transportation and deprives the Afghan government of much needed funds (UNODC, 2009). High-level or "grand" corruption is associated with corrupt acts carried out by politicians as well as other top country officials and those with administrative positions (UNODC, 2009). According to Afghan Counter Narcotic officials (Blanchard, 2009), high government officials, governors and police commanders are involved in the business of drug trade. The report also identified the former warlords and commanders still in power and serve as district chief officers and the local police as the major problem regarding corruption, particularly in the Ministry of Interior. Likewise, in northern Afghanistan, numerous state actors who in preceding years were involved in the trafficking of opiate are now politicians, public officials and businessmen. These stakeholders are continually involved in the business of drug trafficking, bringing about high-level corruption (UNDC, 2012).

\subsection{Corruption in Drug Trafficking Routes}

Corruption is of course not limited to producer's countries in ECO. Transnational trafficking networks have so far been able to take advantage of corruption in the region to transport tens of thousands of metric tons of precursors into Afghanistan and ship hundreds of tons of opiates to Europe via the Islamic Republic of Iran, Pakistan, Turkey and Central Asia (UNODC, 2009). Besides Afghanistan, other ECO members also suffer from corruption associated to drug trafficking (silkroadstudies.org) with both low level and high level of corruption promoting many sectors of society, including public sector and the private sector, the military and political parties (transparency.org). According to Bovenkerk and Yesilgoz (2004), the annual drug trade in Turkey was US $\$ 50$ billion in the late 1990s, which exceeded the total Turkish state budget.

On the other hand, in Central Asians countries, new members of ECO organization, large parts of the political and law enforcement establishment are critically undermined by being involved in the drug trade. As a matter of fact, all of Central Asian countries are affected by illicit drug trade corruption (UNODC, 2012). The effects of embedded corruption in the government make favorable environment for organized crime in Central Asian countries, unintended consequences that emerge in the transition to the democratic system (Cengiz, 2010) and inability or insufficiencies to develop law enforcement in Central Asian countries. This helps strengthen organized crime groups and there are some factors that lead to corruption in these countries. Attempts to transition to a democratic regime failed in Kazakhstan, Uzbekistan, and Turkmenistan and resulted in a transition to more authoritarianism (Collins, 2012).

In Kazakhstan and Uzbekistan, for example, in the 1990s, organized crime groups paid approximately US $\$ 10,000$ to judges in order to release a low-level group member (Holmes, 2009). Approximately fifty percent of the Tajik population believes that the almost all officials take bribes (Centre for Strategic Studies under the President of Tajikistan \& UNDP Tajikistan, 2011). The average monthly salary of a police officer is around 50 dollars in a month, therefore, police officers inevitably tend to take bribes rather than to enforce laws (Cengiz, 2010). In many such cases, officers are being paid to disregard rather than for active participation in the smuggling process (UNODC, 2012).

\section{Money Laundering}

Corruption among ECO member states is not just limited to taking bribes by high government officials or law enforcements. Money laundering is another important part of corruption in ECO area and is linked to drug trafficking. Money laundering has gradually, increasingly become a serious threat for ECO's economy. Money laundering can potentially have devastating effect on economy, security, and society. It paves the ground for drug 
dealers, illegal arms dealers, terrorists, corrupt public officials, as well as others to operate and spread out their criminal enterprises (McDowell, 2001). Based on information in the region, it is claimed that organized crime groups transfer billions of dollars through underground banking systems such as Havala and Hundi, which are informal money transfer networks (Passas, 2005). In such systems, it is not possible to know how much money is transferred for drugs, donations, payment for weapons or other supplies needed for drug trafficking. The United Nations and The World Bank calculated that Hawala dealers just in provinces of Helmand and Kandahar transfer more than $\$ 1$ billion of money obtained from drug trade yearly (Thompson, 2007). In this vein, Senior Pakistani officials confirm that an overwhelming amount of money, i.e., one-third of Pakistan's $\$ 8$ billion Hawala trade is believed to be related to drug trafficking. Also, there is report that Turkish organized crime groups have become involved in an array of legal businesses to launder proceeds of heroin trafficking (EU Organized Crime Report, 2004).

\section{Conclusion}

Corruption has posed major challenges to the efforts taken to control drug and also has seriously damaged the ECO members' image in international community. In this vein, the organized crime squads and insurgents, including the Taliban, has discovered that the most effective way is to take advantage of weak government institutions. Targeting government as well as administrative officials, who are assailable to corruption, can undermine government authenticity and consequently ensures greater leverage (Zarif, 2008). Therefore, the Taliban and associated rebels are not monopolizing the protection of the drug trade. Instead, they form close relationships with Afghan local government administrators, political leaders and police equally (Zarif, 2008). Corruption is not an issue limited to ECO region. In fact, it extends beyond the ECO region, including targeting countries. Accordingly, international donors are required to take sustained efforts and refocus significant energy (UNODC, 2009).

Undoubtedly, fighting against corruption in ECO region is a joint responsibility of international and intercontinental community and this responsibility requires collective action and cooperation among countries in the region. Given the importance of the fight against corruption, it appears to be a new chapter of the negotiations agenda discussed between ECO countries. Also, the battle against corruption is claimed to be directly connected to finding solutions for other problematic areas including the war on drugs, human rights, investment promotion, distinct democratization processes, and economic development (Garrido, 1997). Similarly, many bottom-up initiatives have commenced in ECO to fight corruption, which need to be promoted. The ECO members and the international community are under pressure to take such initiatives for greater transparency as well as effective action to fight corruption. One of the practical solutions is responsibility of ECO organization in implementing rule of law in the region.

\section{References}

Andreas, P. (1996). The Political Economy of Narco-Corruption in Mexico. Retrieved March 4, 2015, from http://www.brown.edu/Departments/Political_Science/people/documents/ThePoliticalEconomyofNarco-Cor ruptioninMexico.pdf

Anticorruption Policy. (1998). Retrieved March 4, 2015, from http://www.adb.org/documents/anticorruptionpolicy

Barro, R. J. (1991). Economic Growth in a Cross Section of Countries. Quarterly Journal of Economics, 106, 407-443. http://dx.doi.org/10.2307/2937943

Beittel, J. S. (2013). Mexico's Drug Trafficking Organizations: Source and Scope of the Rising Violence. CRS Report for Congress Prepared for Members and Committees of Congress.

Blanchard, C. M. (2009, October 7). Afghanistan: Narcotics and U.S. Policy, Congressional Research Service. Retrieved from https://www.fas.org/sgp/crs/row/RL32686.pdf

Bovenkerk, F., \& Yesilgoz, Y. (2004). The Turkish Mafia and the State, Organized Crime in Europe. In C. Fijnaut, \& L. Paoli (Eds.), Springer, The Netherlands (pp. 585-603).

Carvajal, R. (1999). Large-Scale Corruption: Definition, Causes, and Cures. Systemic Practice and Action Research, 12(4), 335-353. http://dx.doi.org/10.1023/A:1022492112414

Cengiz, M. (2010). The Globalization of Turkish Organized Crime and the Policy Response (Doctor of Philosophy). George Mason University.

Centre for Strategic Studies under the President of Tajikistan \& UNDP Tajikistan. (2011). Corruption in Tajikistan:public opinion. Retrieved from http://www.undp.tj/files/undpeng.pdf 
Checchia, M. (2012). Corruption \& the Afghan Security Forces, Part 6 Ofa 6-Part Series on Corruption and Anti- Corruption Issues in Afghanistan. Retrieved from http://reliefweb.int/sites/reliefweb.int/files/res ources/CFC-Afghanistan- Corruption-Volume-Feb2012.pdf

Collins, K. (2002) Clans, Pacts, and Politics in Central Asia. Journal of Democracy, 13(3), 137-152. http://dx.doi.org/10.1353/jod.2002.0041

Corruption Perceptions Index. (2012). Retrieved March 5, 2015, from Http://Www.Transparency.Org/Cpi2012/ Results

Country Factsheets, Eurasian Narcotics Turkey. (2004). Retrieved October 21, 2014, from http://www.silkroadstudies.org/new/inside/research/narcotics_crime/FactSheet/2004/Turkey.pdf

Economic Cooperation Organization (ECO). Retrieved March 23, 2015, from http://www.ecosecretariat.org/ in $2 . h t m$

EU Organized Crime Report. (2004). Retrieved March 4, 2015, from http://www.europol.europa.eu/ publications/Organised_Crime_Reportsin_2006_replaced_by_OCTA/EUOrganisedCrimeSitRep2004.pdf

Garrido, R. S. (1997). Corruption, Drug Trafficking and the Armed Forces. Retrieved March 5, 2015, from http://www.tni.org/article/corruption-drug-trafficking-and-armed-forces

Holmes, L. (2009) Crime, Organized Crime and Corruption in Post-Communist Europe and the CIS. Communist and Post-Communist Studies, 42(2), 265-287. http://dx.doi.org/10.1016/j.postcomstud.2009.04.002

How Do You Define Corruption? Retrieved March 4, 2015, from http://www.transparency.org/whoweare/ organisation/faqs_on_corruption

Jelsma, M., \& Kramer, T. (2009). Redefining Targets Towards a Realistic Afghan Drug Control Strategy, Drug Policy Briefing NR 3D. Retrieved from https://www.unodc.org/documents/afghanistan//Further_Reading/ 2009_TNI_BetterTargets_ANDCS.pdf

MacCoun, R. J. (2001). Peter Reuter, Drug War Heresies: Learning from Other Vices, Times, and Places (pp. 106-107). Cambridge University Press, Cambridge. http://dx.doi.org/10.1017/CBO9780511754272

Maseh, Z. (2008). Counter-Narcotic Strategy in Afghanistan: Internal Implications and External Lessons (Degree of Master of Arts in Liberal Studies). Georgetown University.

Mauro, P. (1997). Why Worry about Corruption. Retrieved March 5, 2015, from http://www.imf.org/EXTERN AL/PUBS/FT/ISSUES6/

McDowell, J. (2001). The Consequences of Money Laundering and Financial Crime, Senior Policy Adviser, and Gary Novis, Program Analyst, Bureau of International Narcotics and Law Enforcement Affairs, U.S. Department of State. Retrieved from http://www.hsdl.org/?view\&did=3549

Myint, U. (2000). Corruption: Causes, Consequences and Cures. Asia-Pacific Development Journal, 7(2) 33-58.

Naylor, T. R. (2009). Violence and Illegal Economic Activity: A Deconstruction. Crime, Law and Social Change, 52(3), 231-242. http://dx.doi.org/10.1007/s10611-009-9198-9

Palau, R. G. (2011). Corruption \& Infrastructure in Afghanistan, Part 3Ofa 6-Part Series on Corruption and Anti-Corruption Issues in Afghanistan. Retrieved from http://reliefweb.int/sites/reliefweb.int/files/resources/ CFC- Afghanistan-Corruption-Volume-Feb2012.pdf

Passas, N. (2005). Informal Value Transfer Systems, Terrorism and Money Laundering. Retrieved from http://www.ncjrs.gov/pdffiles1/nij/grants/208301.pdf

Peters, G. (2009). How Opium Profits The Taliban. Retrieved from http://www.usip.org/sites/default/files/r esources/taliban_opium_1.pdf

Pimental, S. A. (2003). Mexico's Legacy of Corruption. In R. Godson (Ed.), Menace to Society: Political Criminal Collaboration around the World (pp. 175-198). Piscataway, NJ: Transaction.

Shelley, L. (2005). The Unholy Trinity: Transnational Crime, Corruption, and Terrorism. Brown Journal of World Affairs, 11(2), 101-111.

Thompson, E. (2007). The Nexus of Drug Trafficking and Hawala in Afghanistan. In W. Byrd, \& D. Buddenberg (Eds.), Afghanistan's Drug Industry (pp. 177-179). New York: United Nations Office on Drugs and Crime/World Bank.

United Nation Office on Drug and Crime (UNODC). (2009). Addiction, Crime and Insurgency the Transnational 
Threat of Afghan Opium. Retrieved from https://www.unodc.org/documents/data-and-analysis/Afghanistan/ Afghan_Opium_Trade_2009_web.pdf

United Nations Office on Drugs and Crime (UNODC). (2011). The Global Afghan Opium Trade A Threat Assessment, E.11.Xi.11, This Report Was Prepared By UNODC Studies and Threat Analysis Section (STAS).

United Nations Office on Drug and Crime (UNODC). (2012). Opiate Flows through Northern Afghanistan and Central Asia. Retrieved from https://www.unodc.org/documents/data-and-analysis/Studies/Afghanistan northern_route_2012_web.pdf

\section{Copyrights}

Copyright for this article is retained by the author(s), with first publication rights granted to the journal.

This is an open-access article distributed under the terms and conditions of the Creative Commons Attribution license (http://creativecommons.org/licenses/by/3.0/). 